\title{
Nitric oxide enhances Oct-4 expression in bone marrow stem cells and promotes endothelial differentiation
}

\author{
Ling Chu ${ }^{\mathrm{a}, \mathrm{c}}$, Yuehua Jiang ${ }^{\mathrm{b}}$, Hong Hao ${ }^{\mathrm{a}}$, Yong Xia ${ }^{\mathrm{a}}$, Jian $\mathrm{Xu}^{\mathrm{a}}$, Zehao Liu ${ }^{\mathrm{a}}$, Catherine M. Verfaillie ${ }^{\mathrm{b}}$, \\ Jay L. Zweier ${ }^{\text {a }}$, Zhenguo Liu ${ }^{\text {a,* }}$ \\ a Davis Heart \& Lung Research Institute and Division of Cardiovascular Medicine, The Ohio State University Medical Center, Columbus, Ohio, United States \\ b Stem Cell Institute, University of Minnesota Medical School, Minneapolis, Minnesota, United States \\ c Department of Pathology, Xiangya Third Hospital of Central South University, Changsha, Hunan, China
}

\section{A R T I C L E I N F O}

\section{Article history:}

Received 12 December 2007

Received in revised form 23 May 2008

Accepted 5 June 2008

Available online 22 June 2008

\section{Keywords:}

MAPCs

Nitric oxide

Differentiation

Stem cell

Endothelial cell

\begin{abstract}
A B S T R A C T
This study was designed to investigate the role of nitric oxide (NO) in bone marrow stem cells and their differentiation into endothelial cells in vitro. Adult mouse bone marrow multipotent progenitor cells (MAPCs) were used as the source of stem cells. Oct-4 expression (both mRNA and protein) was significantly increased by up to $68.0 \%$ in MAPCs when incubated with NO donors DETA-NONOate or sodium nitroprusside (SNP) in a concentration-dependant manner $(n=3, P<0.05)$. However, the cell proliferation was dramatically decreased by over 3 -folds when treated with DETA-NONOate or SNP for $48 \mathrm{~h}(n=3, \mathrm{P}<0.05)$. When MAPCs were exposed to DETA-NONOate $(100 \mu \mathrm{M})$ for the first $48 \mathrm{~h}$ during differentiation, the expression (both mRNA and protein) of vWF was significantly increased at day 14 in the differentiating cells. The effects of DETA-NONOate or SNP on cell proliferation, Oct-4 expression and endothelial differentiation of MAPCs were not affected by the guanylyl cyclase inhibitor $1 H$-[1,2,4] oxadiazolo[4,3-a]quinoxalin-1-one or cGMP analog 8Br-cGMP. These data indicate that NO may regulate both the pluripotency and differentiation of MAPCs via a cGMP-independent mechanism.
\end{abstract}

(c) 2008 Elsevier B.V. All rights reserved.

\section{Introduction}

Nitric oxide (NO) is a very reactive molecule that has multiple biological effects on a variety of organ systems including cardiovascular, neurological, and immune systems (Moncada and Higgs, 1993; Nathan, 1992). Accumulating evidence indicates that NO plays an important role in stem cell proliferation and differentiation. It has been reported that at physiological concentrations NO functions as a negative regulator of stem/progenitor cell proliferation, and is critical to the initiation of cell differentiation (Cheng et al., 2003; Peunova and Enikolopov, 1995; Wingrove and O'Farrell, 1999). It has been demonstrated that NO modulates the growth and differentiation of human erythroid and myeloid cells from CD34+ bone marrow cells in vivo (Shami and Weinberg, 1996). NO also promotes bone and chondrocyte terminal differentiation (Teixeira et al., 2005), participates in early neuronal development and differentiation in mouse (Arnhold et al., 2002, 1999), stimulates preadipocyte differentiation in rat (Yan et al., 2002), and mediates osteoblastic differentiation (Pan et al., 2005). In addition, NO synthase inhibitors have been shown to arrest the differentiation toward a cardiac phenotype from mouse

\footnotetext{
* Corresponding author. Davis Heart \& Lung Research Institute, The Ohio State University Medical Center, Room 260 DHLRI; 473 West 12th Ave, Columbus, OH 43210, United States. Tel.: +1 614247 8435; fax: +1 6142935614 .

E-mail address: zhenguo.liu@osumc.edu (Z. Liu).
}

embryonic stem cells that is readily to be rescued by NO donors (Bloch et al., 1999).

The understanding of the mechanisms underlying the actions of NO on cell growth and differentiation remains incomplete. Although soluble guanylate cyclase (sGC)-cGMP signal transduction pathway is believed to be a major target for NO in cardiovascular system (Nathan, 1992), NO may function through a mechanism independent of sGC/ cGMP signaling pathway. NO, for example, has been reported to be a critical mediator for neurogenesis during early stages of embryonic stem cell differentiation via a mechanism independent of sGC/cGMP pathway, possibly by mediating the intracellular calcium homeostasis (Arnhold et al., 2002).

Stem cells exhibit unique characteristics including specific cell markers and gene expression such as the transcription factor Oct-4 (Ben-Shushan et al., 1998; Niwa et al., 2000; Vassilieva et al., 2000). Oct-4 is expressed at high level in embryonic stem cells (Ben-Shushan et al., 1998). Reyes et al. (2001) recently purified and cultured bone marrow multipotent progenitor cells (MAPCs) from human, rat and mouse that expressed Oct- 4 and were able to differentiate into multiple cell lineages including endothelial cells and neurons (Liu et al., 2007; Ulloa-Montoya et al., 2007). However, whether NO could affect the differentiation of MAPCs is unknown. The purpose of the present study was to determine the effects of $\mathrm{NO}$ on the expression of Oct-4 in MAPCs and their differentiation into endothelial cells. Our data showed that NO inhibited the proliferation of MAPCs, enhanced 
Oct-4 expression, and promoted endothelial differentiation of MAPCs through a mechanism independent of cGMP pathway.

\section{Materials and methods}

\subsection{Materials}

Sodium nitroprusside (SNP), 8-bromoguanosine-3ॄ, 5\$-cyclomonophosphate sodium salt (8-Br-cGMP), and $1 H$-[1,2,4]oxadiazolo[4,3a]quinoxalin-1-one (ODQ) were from Sigma (St. Louis, MO). Diethylamine NONOate diethylammonium salt (DETA-NONOate) was from Cayman Chemical (Ann Arbor, MI). Vascular endothelial growth factor (VEGF) was from R\&D (Minneapolis, MN). Antibodies (Ab) against von Willebrand factor (vWF), Oct-4, and tubulin were from Santa Cruz Biotechnology (Santa Cruz, CA). Anti-goat IgG-Cy-3 was from sigma. ECL labeling and detection system was from Amersham Biosciences (Piscataway, NJ).

\subsection{Cell culture and proliferation}

Adult mouse bone marrow multipotent progenitor cells (MAPCs) were used as the source of bone marrow stem cells, and cultured with the method described previously in detail (Breyer et al., 2006). Briefly, undifferentiated MAPCs were maintained in expansion medium at $37{ }^{\circ} \mathrm{C}$ with $5 \% \mathrm{O}_{2}, 5 \% \mathrm{CO}_{2}$ and $90 \% \mathrm{~N}_{2}$ with cell density of 200 cells $/ \mathrm{cm}^{2}$ and media change every other day. To investigate the effects of $\mathrm{NO}$ on the proliferation of MAPCs, the cells were incubated for up to $48 \mathrm{~h}$ in expansion medium in the presence of NO-generating agents DETANONO ate ( $50 \mu \mathrm{M}$ and $100 \mu \mathrm{M}$ ) or SNP (from $100 \mu \mathrm{M}$ to $2,000 \mu \mathrm{M}$ ). NO release from these NO donors in the media was confirmed using electron paramagnetic resonance (EPR) technique as described previously (Cardounel et al., 2007; Xia et al., 2000). Cells were counted and collected at 12,24 , and $48 \mathrm{~h}$ after exposure to NO donors to determine the expression level of stem cell specific marker Oct-4 in MAPCs with real-time PCR and Western blot analysis as described below. To demonstrate any dependence of the actions of DETANONOate and SNP on cyclic GMP, experiments were repeated in the presence of specific guanylyl cyclase inhibitor ODQ $(25 \mu \mathrm{M})$ or cGMP analog 8-Br-cGMP (250 and $500 \mu \mathrm{M})$.

\subsection{Endothelial differentiation}

Endothelial differentiation of MAPCs was induced with the method described in detail previously in the presence of VEGF (Liu et al., 2007; Ulloa-Montoya et al., 2007). Briefly, MAPCs were cultured at a density of $4-5 \times 10^{4}$ cells $/ \mathrm{cm}^{2}$ in fibronectin(FN)-coated culture vessels in serum-free media in the presence of $10 \mathrm{ng} / \mathrm{ml} \mathrm{VEGF}$ at $37{ }^{\circ} \mathrm{C}$ with $5 \%$ $\mathrm{O}_{2}, 5 \% \mathrm{CO}_{2}$, and $90 \% \mathrm{~N}_{2}$. Culture medium was changed every two days. To evaluate the effects of NO and cGMP signaling on the differentiation of MAPCs into endothelial cells, the NO donor DETA-NONOate $(50 \mu \mathrm{M}$ and $100 \mu \mathrm{M}$ ) was added to the culture media with or without ODQ $(25 \mu \mathrm{M})$ or 8 -Br-cGMP $(500 \mu \mathrm{M})$. Cells were collected at days $0,7,10$, and 14 of differentiation for real-time PCR and Western blot analysis to determine the expression of endothelial cell marker vWF.

\subsection{Quantitative real-time PCR}

Quantitative real-time PCR assay was used to determine Oct- 4 and vWF mRNA levels in the undifferentiated and differentiating MAPCs at days $0,7,10$, and 14 using RNeasy kit (Qiagen) with the method described previously (Jiang et al., 2002; Ulloa-Montoya et al., 2007). mRNA was reverse-transcribed (Applied Biosystems), and the synthesized cDNA underwent 40 rounds of amplification (ABI PRISM 7700, Perkin-Elmer/Applied Biosystems) with the following reaction conditions: 40 cycles $\left(95{ }^{\circ} \mathrm{C}\right.$ for $15 \mathrm{~s}$ and $60{ }^{\circ} \mathrm{C}$ for $1 \mathrm{~min}$ ) after initial denature $\left(50{ }^{\circ} \mathrm{C}\right.$ for $2 \mathrm{~min}$ and $95{ }^{\circ} \mathrm{C}$ for $10 \mathrm{~min}$ ), followed by $95{ }^{\circ} \mathrm{C}$ for
$15 \mathrm{~s}$ and $60^{\circ} \mathrm{C}$ for $20 \mathrm{~min}$. Controls consisted of amplifications without reverse transcription and reactions without addition of cDNA template. The primer sequences were: 5-CCAATCAGCTTGGGCTAGAG3 and 5-CCTGGGAAAGGTGTCCTGTA-3 for Oct-4; 5-GCCAAAGATCTGGAACAGTGT-3 and 5-GATGGAGAGGTTACACATCTC-3 for vWF; and 5CATGGCCTTCCGTGTTCCTA-3, 5-CTGGTCCTCAGTGTAGCCCAA-3 for GAPDH. The mRNA levels were normalized by using GAPDH as housekeeping gene and compared with levels in mouse embryos for Oct-4 or mouse universal gene for vWF.

\subsection{Western blot analysis}

Cells were collected in the form of a pellet by centrifugation at $600 \mathrm{~g}$ for $5 \mathrm{~min}$ at $4{ }^{\circ} \mathrm{C}$ and lysed with lysis buffer as previously described (Gallagher et al., 2007). The supernatant was collected for analysis after centrifugation at $14,000 \mathrm{~g}$ for $15 \mathrm{~min}$ at $4^{\circ} \mathrm{C}$. Protein concentration was determined by the BCA protein assay (Piece, Rockford, IL). A total of $40 \mathrm{mg}$ protein was loaded on 6\% SDS-polyacrylamide gel, and immunoblotting was conducted as previously described (Yang et al., 2006). The dilution factor for the primary Abs against vWF, Oct-4, and $\beta$-tubulin was 1:200,1:500, and 1:1000, respectively, as recommended by the manufacturers. The protein levels were determined using horseradish peroxidase-linked secondary Abs and ECL System. All Western blot experiments were repeated for at least three times.

\subsection{Immunofluorescence staining for $v W F$}

Undifferentiated or differentiating MAPCs were plated in FNcoated chamber slides. At days $0,7,10$, and 14 of differentiation, cells were fixed with $2 \%$ paraformaldehyde for $4 \mathrm{~min}$ at room temperature. The cells were further prepared for immunofluorescence staining for vWF as described previously (Jiang et al., 2002). The dilution factor for the primary $A b$ against $v W F$ was $1: 100$, and for the secondary $A b$ (anti-goat IgG-Cy-3, from Sigma) was 1:200. Cells exposed to the secondary Ab only were used as negative controls; and cultured human umbilical vein endothelial cells (HUVEC) were used as positive control.

\subsection{In vitro tube formation assay}

In vitro vascular tube formation from the cells differentiated from MAPCs was evaluated in three-dimensional growth factor reduced Matrigel (10 mg/ml; Collaborative Research, Bedford, MA) as described previously (Gupta et al., 1999; Liu et al. 2007). MAPCderived endothelial cells $\left(5 \times 10^{4}\right.$ total) were seeded in serum-free and growth factor-free medium on the surface of Matrigel (previously polymerized over night). Cultures were incubated with VEGF (10 ng/ $\mathrm{ml}$ ) at $37{ }^{\circ} \mathrm{C}$, and observed for tube formation every hour. Human dermal microvascular endothelial cells (MEC) and fibroblasts were used as positive and negative controls, respectively.

\subsection{Statistical analysis}

The data were expressed as mean \pm S.D. and statistically analyzed by independent sample $t$-test or by one-way ANOVA followed by LSD post hoc tests when appropriate. It was considered statistically significant when $P<0.05$.

\section{Results}

\subsection{Effects of NO on cell proliferation and Oct-4 expression in MAPCS}

As shown in Fig. 1A, both DETA-NONOate and SNP significantly inhibited the proliferation of MAPCs in a concentration-dependent manner as reflected by decreased cell number in culture. The cell number was decreased from $1.68 \pm 0.03 \times 10^{3} / \mathrm{cm}^{2}$ to $1.18 \pm 0.04 \times 10^{3} /$ 
A

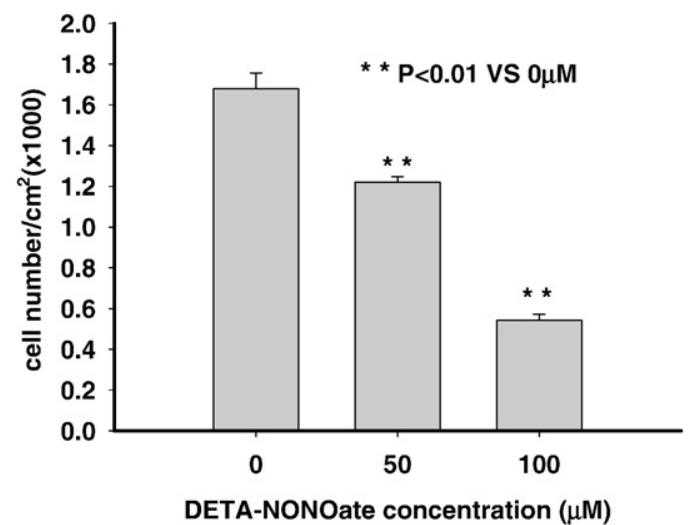

C

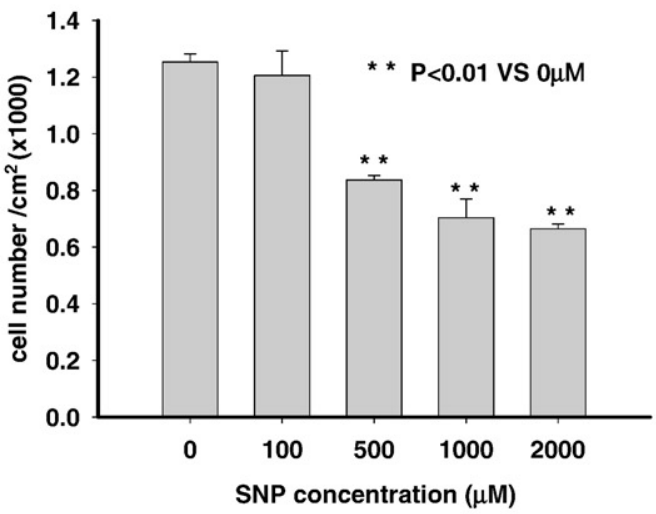

B $\rightleftarrows$ Control

DETA-NONOate $100 \mu \mathrm{M}$

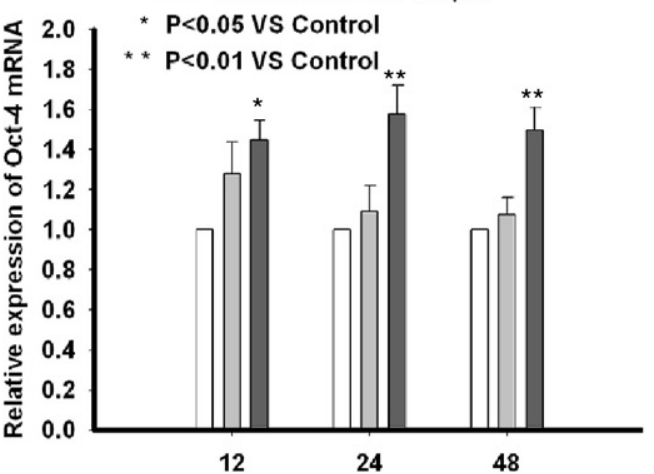

12

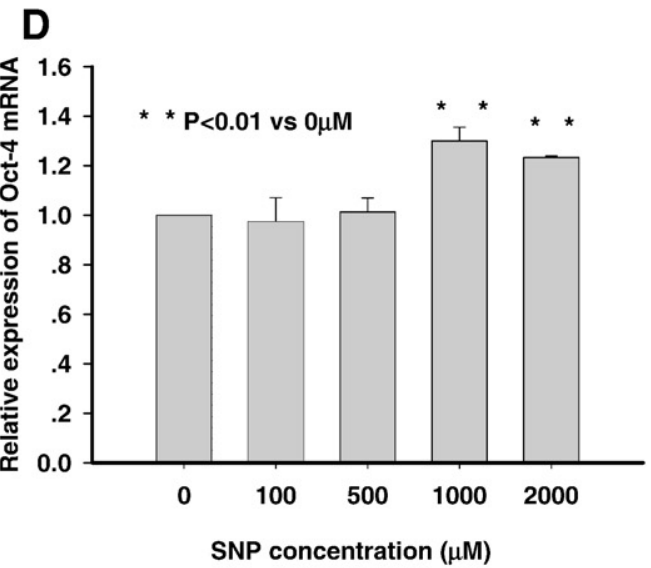

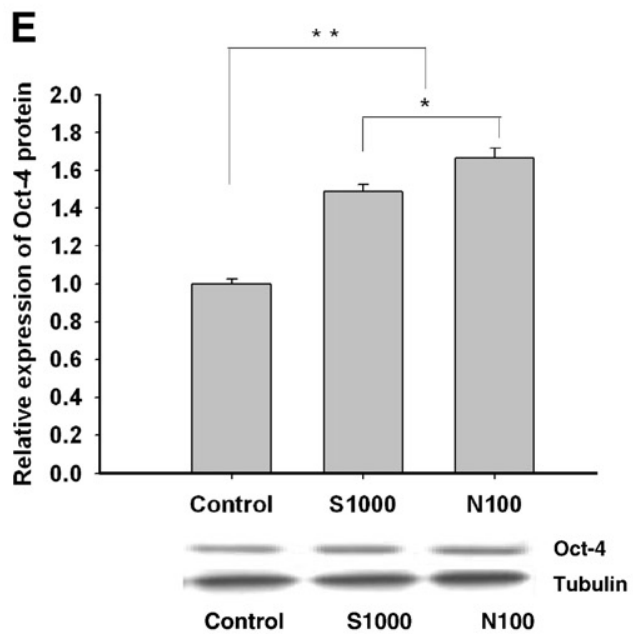

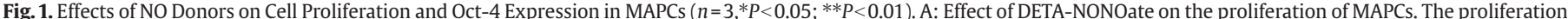

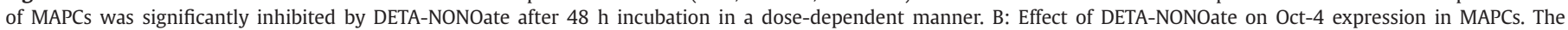

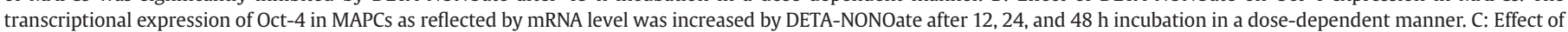

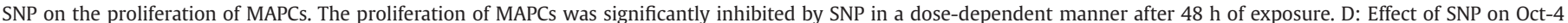

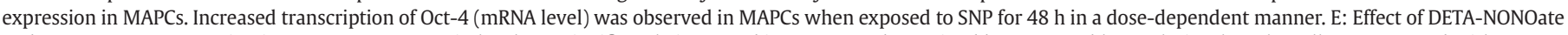

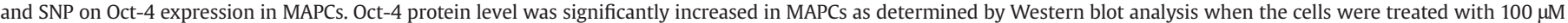
DETA-NONOate (N100) or $1000 \mu \mathrm{M}$ SNP (S1000) for $24 \mathrm{~h}$.

$\mathrm{cm}^{2}(n=3, P<0.05)$ when exposed to $50 \mu \mathrm{M}$ DETA-NONOate, and further decreased to $0.54 \pm 0.08 \times 10^{3}$ with $100 \mu \mathrm{M}$ DETA-NONOate $(n=3, P<0.05)$ after $48 \mathrm{~h}$ of culture. To make sure that the decreased cell number was not secondary to increased cell death, Trypan Blue staining assay showed no cell death when cultured with $100 \mu \mathrm{M}$ DETA-NONOate for $48 \mathrm{~h}$. However, when its concentration was over
$100 \mu \mathrm{M}$, cell death occurred to the majority of the cells (data not shown). Similarly, a significant decrease in cell proliferation of MAPCs was observed in a dose-dependent manner when the cells were exposed to another NO donor SNP as shown in Fig. 1C. However, SNP was toxic to MAPCs with cell death when its concentration was beyond $2.0 \mathrm{mM}$ (data not shown). 
Oct-4 expression was significantly increased in the cells treated with either DETA-NONOate or SNP in a concentration-dependent manner as shown in Fig. 1B and D. The baseline level of Oct- 4 mRNA as measured by quantitative real-time PCR in MAPCs was $24.2 \pm 2.0 \%$ $(n=5)$ of that in embryonic stem cells. This result was consistent with previous observations (Luttun et al., 2005; Ulloa-Montoya et al., 2007). The baseline expression of Oct-4 in MAPCs was further confirmed using Western blot analysis as shown in Fig. 1E. When incubated with DETA-NONOate at $100 \mu \mathrm{M}$, the Oct- 4 mRNA levels in the cells was significantly increased by $51.0 \pm 11.0 \%(n=3, P<0.05)$ after $12 \mathrm{~h}$ of treatment, and by $58.0 \pm 12.0 \%(n=3, P<0.05)$ after 48 h over baseline. There was no significant change in Oct- 4 expression in the cells when exposed to $50 \mu \mathrm{M}$ DETA-NONOate (Fig. 1B), indicating that it was dosedependent. A significant increase in Oct-4 mRNA level was also observed by over $30 \%(n=3, P<0.05)$ in the cells when treated with SNP in a dose-dependent manner as shown in Fig. 1D. However, when SNP concentration was increased to $5 \mathrm{mM}$ in the media, significant cell death occurred (data not shown). In parallel to the change in mRNA, Western blot analysis demonstrated that Oct- 4 protein level was also increased significantly in MAPCs by $68 \%$ and $48 \%$ when the cells were exposed to $100 \mu \mathrm{M}$ DETA-NONOate and $1000 \mu \mathrm{M}$ SNP for $24 \mathrm{~h}$, respectively as shown in Fig. $1 \mathrm{E}(n=3, P<0.001)$, suggesting that Oct- 4 expression is indeed up-regulated by $\mathrm{NO}$ in these cells.

\subsection{Effects of $N O$ on endothelial differentiation}

As shown in Fig. 2, the differentiating cells exhibited cobblestonelike endothelial cell appearance by day 14 of differentiation. The differentiated cells were also stained positive for vWF, and formed capillary tubes on growth factor reduced Matrigel (Fig. 2), suggesting that the differentiated cells are indeed functional endothelial cells. These data were consistent with our previous observations (Reyes et al., 2001; Jiang et al., 2002; Liu et al., 2007; Ulloa-Montoya et al.,
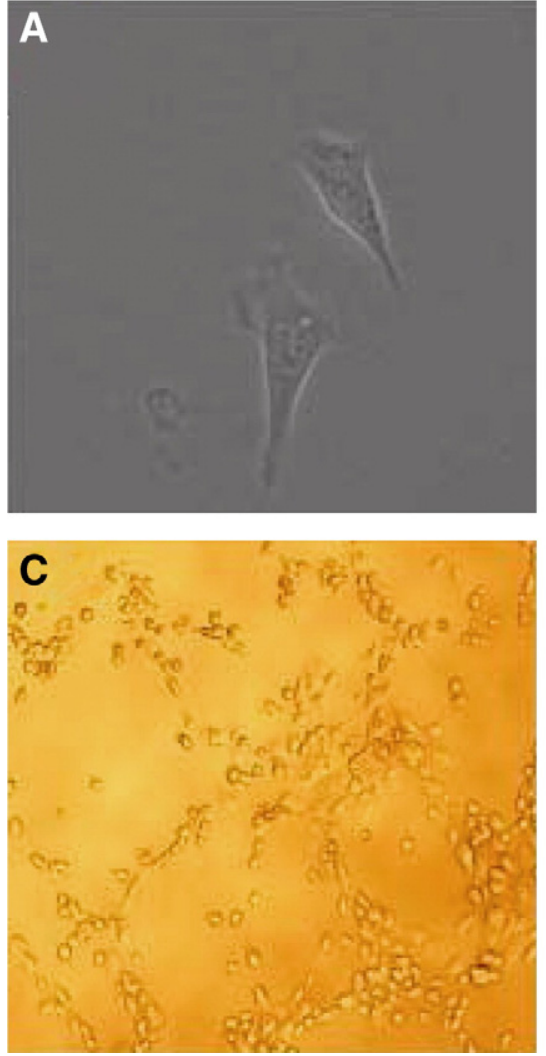

2007). The time-course of vWF expression showed that the differentiating cells started to express vWF at day 7 as evaluated by both mRNA (RT-PCR) and protein (Western blot) (Fig. 3A and C). vWF expression was further increased by 42 times over baseline (day 0 , e.g. prior to differentiation) at day 14 by Western blot analysis (Fig. 3A) and mRNA level (Fig. 3C). When the cells were treated with DETANONOate $(50 \mu \mathrm{M}$ and $100 \mu \mathrm{M})$ during endothelial differentiation, both vWF mRNA and protein levels were increased significantly in a dosedependent manner as shown in Fig. 3B and C. At day 14 of differentiation, there was a $70 \%(n=4, P<0.05)$ increase in vWF mRNA level, and 3-fold $(n=4, P<0.05)$ increase in vWF protein content in the cells treated with DETA-NONOate $(100 \mu \mathrm{M})$ over control (without NO donor). No differentiation experiments were conducted in the presence of SNP due to the concern of cyanide toxicity to the cells that might render the data difficult to interpret.

\subsection{Role of cGMP in NO-mediated actions on MAPCS}

Soluble guanylate cyclase (sGCs) is one of the main intracellular targets of NO (Reykdal et al., 1999), experiments were conducted to investigate whether the cGMP-dependent pathway was involved in the actions of NO donors on MAPCs. It was found that the effects of DETANONOate or SNP on cell proliferation and Oct-4 expression as well as differentiation of the stem cells were not affected in the presence of specific guanylyl cyclase inhibitor ODQ $(25 \mu \mathrm{M})$ or cGMP analog 8-BrcGMP $(250 \mu \mathrm{M}$ and $500 \mu \mathrm{M})$ as shown in Fig. 4. These data indicate that the effects of NO on MAPCs are independent of cGMP-mediated pathway.

\section{Discussion}

It is well known that NO is involved in modulating cell proliferation and differentiation. NO is able to promote cell cycle arrest, and therefore, inhibits cell proliferation in most cases including endothelial progenitor
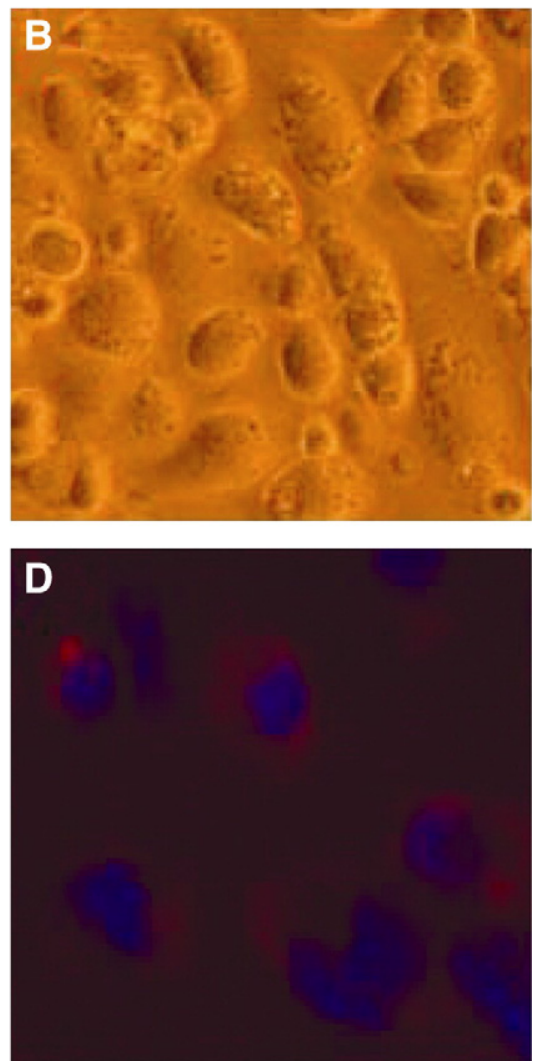

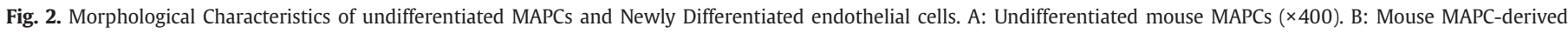

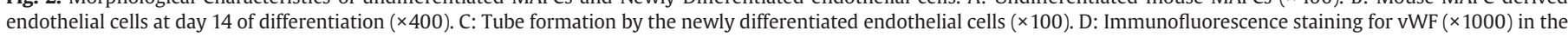
newly differentiated endothelial cells. Almost all the cells stained positive for vWF at day 14 of MAPC differentiation. 


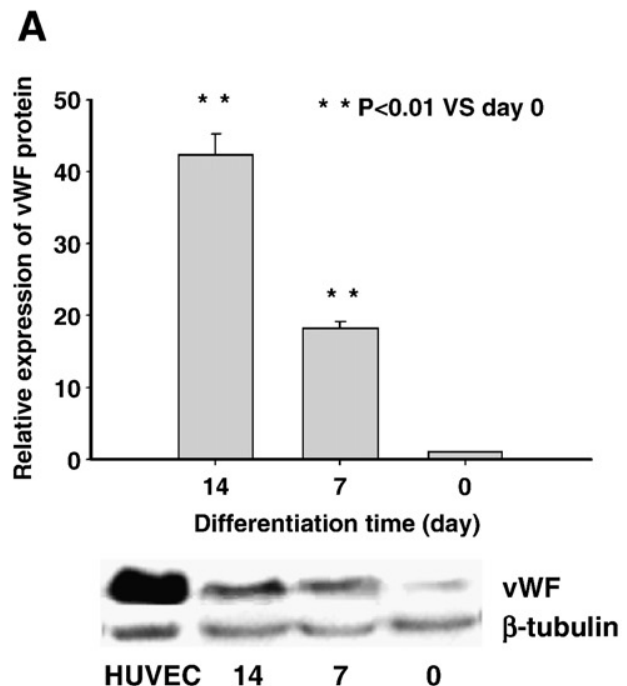

B

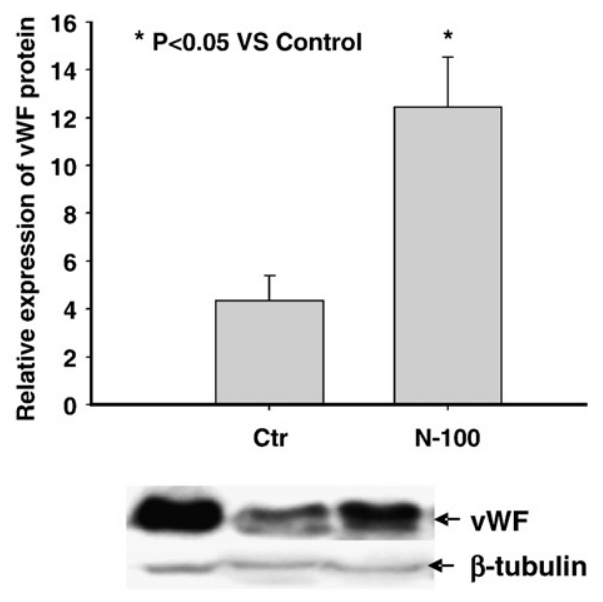

HUVEC Ctr N-100

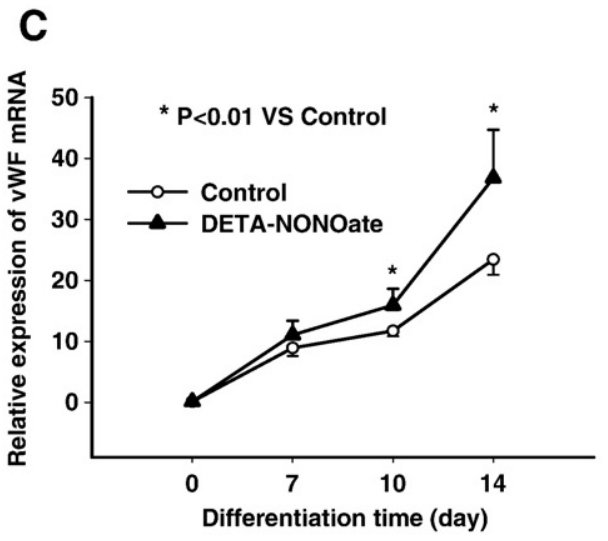

Fig. 3. Effects of NO on vWF expression during endothelial differentiation of MAPCs $\left(n=3, * P<0.05\right.$; $\left.{ }^{* *} P<0.01\right)$. A: Time-dependent expression of $\mathrm{vWF}$ protein during endothelial differentiation as analyzed by Western blot. vWF protein content was increased significantly during the course of endothelial differentiation of MAPCs. B: Effect of DETA-NONOate on vWF expression during endothelial differentiation of MAPCs. The protein level of vWF was significantly increased in the cells when treated with DETA-NONOate $(100 \mu \mathrm{M})$ at day 14 of endothelial differentiation. C: Effect of DETANONOate on the transcriptional expression of vWF during endothelial differentiation of MAPCs. Time-dependent transcriptional expression of vWF (mRNA) was significantly enhanced in the cells when treated with DETA-NONOate during differentiation. Ctr: control; N-100: cells treated with $100 \mu \mathrm{M}$ DETA-NONOate. HUVEC: human umbilical vein endothelial cells. cells (Villalobo, 2006). In our study, MAPC proliferation was significantly decreased by both DETA-NONOate and SNP in a concentrationdependent manner. No cell death was identified under our experimental

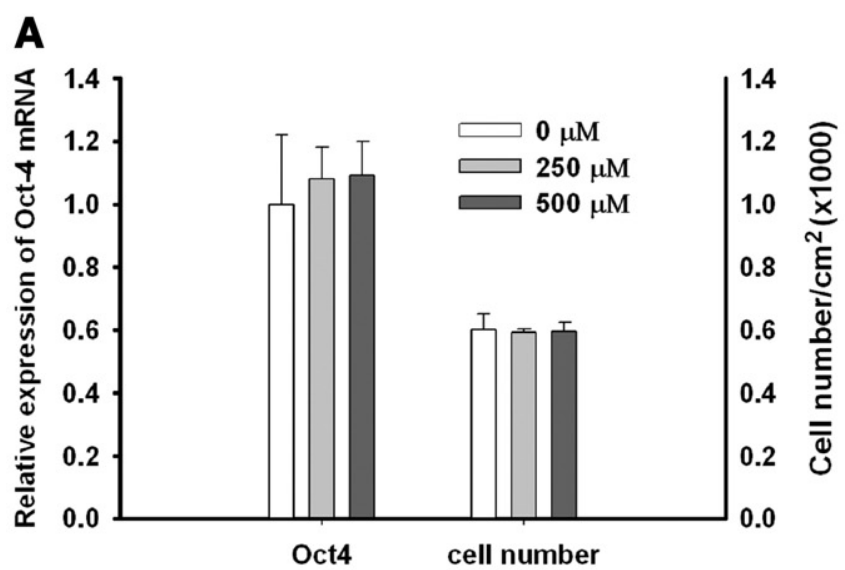

B
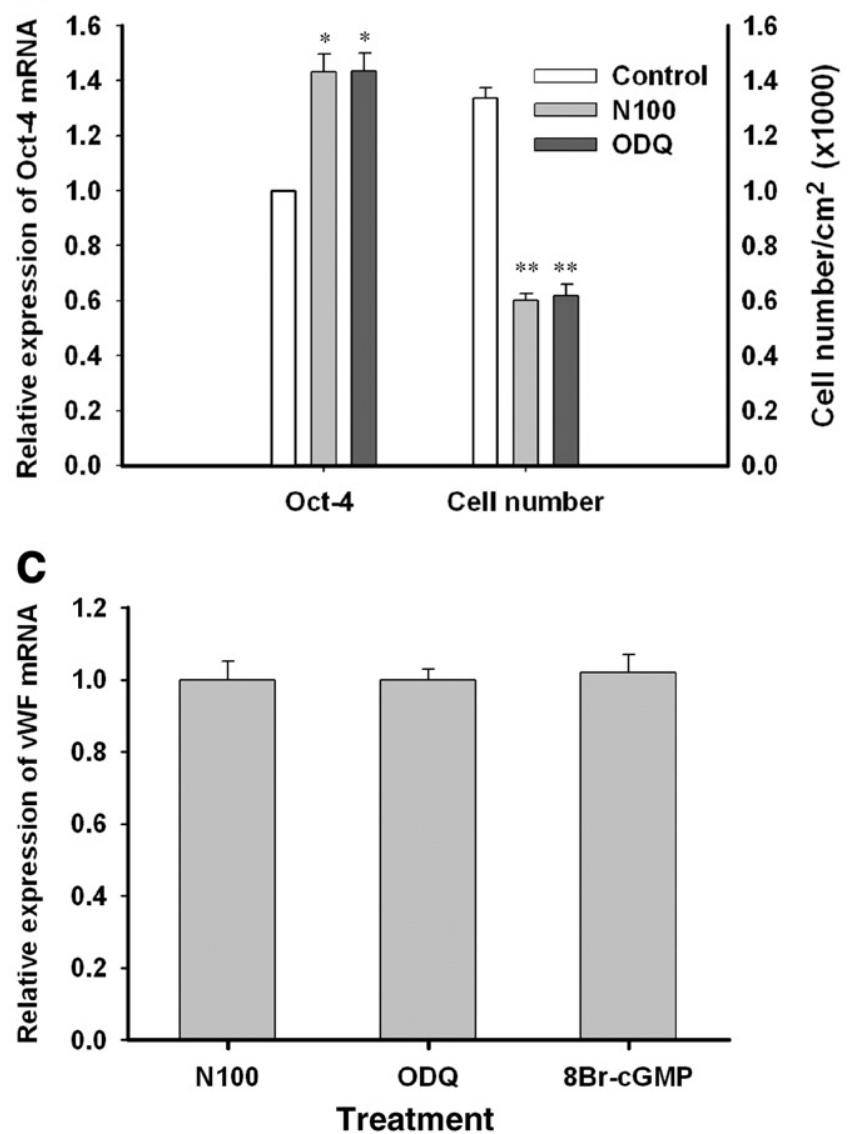

Fig. 4. Role of cGMP in the effects of DETA-NONOate on MAPCs. In a set of parallel experiments, MAPCs were pre-treated with the guanylyl cyclase inhibitor ODQ ( $25 \mu \mathrm{M})$ or cGMP analog 8-Br-cGMP ( $250 \mu \mathrm{M}$ or $500 \mu \mathrm{M})$ for $30 \mathrm{~min}$ prior to exposure to DETANONOate $(100 \mu \mathrm{M})$. A: Effect of 8-Br-cGMP on Oct-4 expression (mRNA) and the proliferation of MAPCs. The Oct- 4 mRNA level in MAPCs and their proliferation were not affected by 8 -Br-cGMP $(n=4, P>0.05)$. B: Effects of ODQ on Oct-4 expression (mRNA) and the proliferation of MAPCs. DETA-NONOate significantly enhanced Oct-4 mRNA level and inhibited MAPC proliferation that were not altered when the cells were pretreated by ODQ $(25 \mu \mathrm{M}, n=4, P>0.05)$. ${ }^{*} P<0.05$; $* * P<0.01$ when compared with control. C: Effects of ODQ and 8-Br-cGMP on the expression of vWF (mRNA). The vWF mRNA level was measured by RT-PCR at day 14 of endothelial differentiation of MAPCs that was not affected by pre-treating the cells with ODQ or 8-Br-cGMP. $(n=4, P>0.05)$. $\mathrm{N}-100$ : cells treated with $100 \mu \mathrm{M}$ DETA-NONOate. ODQ: cells were pre-treated with ODQ $(25 \mu \mathrm{M})$, then incubated with $100 \mu \mathrm{M}$ DETA-NONOate; 8Br-cGMP: cells were pretreated with 8-Br-cGMP $(500 \mu \mathrm{M})$, then incubated with $100 \mu \mathrm{M}$ DETA-NONOate. 
A
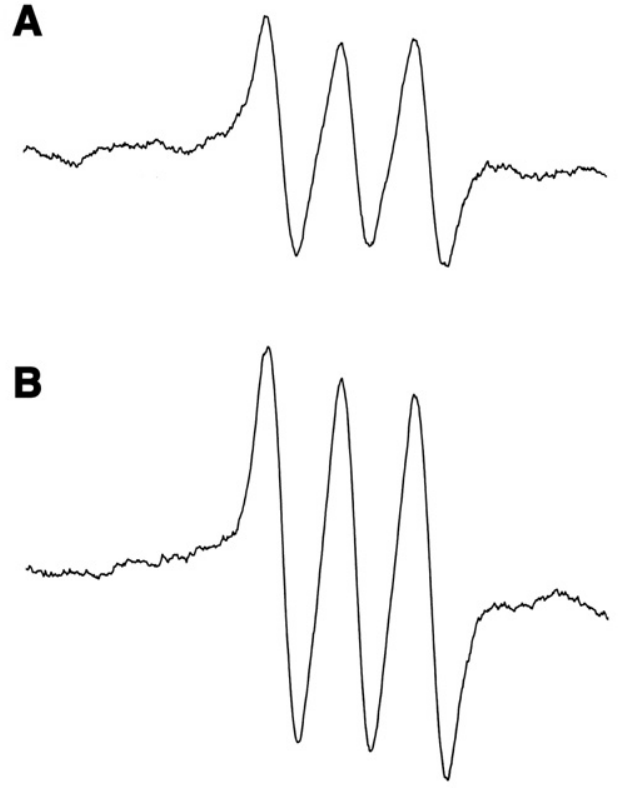

3370

3420

3470

Fig. 5. NO generation from DETA-NONOate as measured by EPR. Significant amount of NO was detected in the culture media at baseline at $2 \mathrm{~h}$ of incubation with $100 \mu \mathrm{M}$ DETA-NONOate (panel A). NO release in the media from DETA-NONOate $(100 \mu \mathrm{M})$ was significantly increased when MAPCs were present in the culture system at $2 \mathrm{~h}$ (panel B).

conditions. These data were consistent with previous observations (Kanno et al., 2004; Peunova and Enikolopov, 1995; Villalobo, 2006).

One of the key findings of the present study is that NO appears to play an important role in both maintaining the pluripotency of MAPCs and promoting their endothelial differentiation. NO has been reported to be involved in endothelial progenitor cell growth and differentiation (Maciejewski et al., 1995; Reykdal et al., 1999). However, the effect of exogenous NO on MAPC biology has not yet been investigated in detail. We therefore treated MAPCs with various NO donors at different concentrations to examine the effects of NO on both stem cell pluripotency and differentiation. We found that exposure of MAPCs to NO donors significantly increased the level of Oct- 4 expression in a dosedependent manner. Oct-4 is a transcription factor of the Pit-oct-Unc (POU) family. These transcriptional factors are expressed in the pluripotent cells of preimplantation embryos and most germ line cells. Oct- 4 expression in mouse embryonic stem cells is widely considered as a hallmark of cell pluripotency and critical to the regulation of embryonic differentiation (Niwa et al., 2000; Pesce and Scholer, 2001). Oct-4 was also expressed abundantly in MAPCs that was demonstrated in the present and previous studies (Luttun et al., 2005; Ulloa-Montoya et al., 2007). It was reported that the levels of pluripotency marker Oct- 4 expression correlated with the endothelial differentiation potential of MAPCs in vitro (Luttun et al., 2005; Ulloa-Montoya et al., 2007). In a recently published study, we found that Oct- 4 expression was decreased dramatically at the very early phase when MAPCs were induced to differentiate into endothelial cells (Xu et al., 2008). Our finding that NO increases Oct-4 expressions in bone marrow stem cells suggests that NO may be important to maintaining their pluripotency. Recently, Danalache et al. (2007) showed that NO synthase inhibitor N,G-nitro-L-arginine-methyl-ester decreased the expression of anti-stage specific embryonic antigen-1 marker of the undifferentiated mouse P19 embryonic carcinoma cells, and inhibited oxytocin-induced differentiation of embryonic and cardiac somatic stem cells into cardiomyocytes. However, future studies including electrophoretic mobility shift assays are needed to refine the mechanisms that are involved in the regulation of Oct- 4 expression by NO in MAPCs.

In the present study, DETA-NONOate and SNP were used as the sources of exogenous NO. These two agents are very different chemically indeed with some similarity. They both release NO rapidly in culture media (Keefer et al., 1996; Marks et al., 1995; Beckman 1999). But, DETANONOate has a long half-life of approximately $22-50 \mathrm{~h}$ in culture media (Keefer et al., 1996; Beckman 1999). On the other hand, the half-life of SNP is estimated to be $12 \mathrm{~h}$ in culture system (Floryszak-Wieczorek et al., 2006). In addition to NO production, SNP also releases cyanide and iron (Ramakrishna Rao and Cederbaum, 1996). Based on previous report (Beckman, 1999), DETA-NONOate at a concentration of $100 \mu \mathrm{M}$ could release $500 \mathrm{nM}$ NO. SNP, however, at a concentration of $100 \mu \mathrm{M}$, could only generate 1.2 nM NO (Marks et al., 1995). The NO release from DETANONOate and SNP was confirmed in our experimental condition as shown in Fig. 5. The data were comparable to the results in previous report (Beckman 1999; Marks et al., 1995). The difference in NO generation from these two donors could explain that high concentrations of SNP were required to achieve similar effects on MAPCs compared to DETA-NONOate. Despite the difference in half-life, both DETA-NONOate and SNP similarly inhibited the proliferation of MAPCs when incubated for up to $48 \mathrm{~h}$. This is a very interesting finding. As a matter of fact, it was reported that significant growth-inhibiting effects of NO on human endothelial cells was observed when the cells were exposed to NO for as short as $10 \mathrm{~min}$ (Heller et al., 1999), suggesting that NO-mediated inhibition of cell proliferation occurs quickly and lasts for a prolonged period of time. It seemed that DETA-NONOate was more potent in increasing Oct-4 expression (especially at protein level) in MAPCs than SNP.

Recent evidence indicates that NO is important in regulating stem cell differentiation such as neurogenesis and cardiomyogenesis (Cheng et al., 2003; Kanno et al., 2004; Krumenacker et al., 2006; Krumenacker and Murad, 2006; Poluha et al., 1997). In the present study, bone marrow stem cells were directed to commit to endothelial differentiation. By day 14 of differentiation, the differentiating cells became functional endothelial cells as reflected by endothelial morphology, positive staining for endothelial marker vWF, and capillary tube formation. These results are consistent with our previous observations (Reyes et al., 2001; Jiang et al., 2002; Liu et al., 2007; Ulloa-Montoya et al., 2007). Addition of NO in the culture system appears to promote the differentiation of MAPCs to endothelial cells as evidenced by the fact that NO donors significantly increased the levels of vWF mRNA and protein. This finding is similar to the results that NO facilitates cardiac differentiation of mouse embryonic stem cells in vitro (Kanno et al., 2004). Our findings in this study that NO inhibits stem cell proliferation, increases Oct-4 expression, and promotes endothelial differentiation of MAPCs reveal a previously unrecognized action of NO on stem cell biology, where the effect of NO is determined by the status of stem cells in pluripotent or differentiating mode.

NO usually functions via either a cGMP-dependent or cGMPindependent mechanism (Krumenacker et al., 2006; Krumenacker and Murad, 2006). It is well known that NO is a major vasodilator and plays a key role in maintaining cardiovascular homeostasis. Endothelial cells synthesize NO that subsequently diffuses into smooth muscle cells, where NO activates sGC leading to cGMP-mediated relaxation. However, it remains unclear whether this classical pathway also mediates the action of NO on stem cell biology. We therefore explored this issue with both sGC inhibitor and cGMP mimic compound. We found that the effect of NO donors on Oct- 4 expression in MAPCs was not affected by sGC inhibitor ODQ or cGMP mimics 8-Br-cGMP. Similar results were also seen for the effect of NO on vWF expression during endothelial differentiation of MAPCs. It is very unlikely that lack of effects of these agents on MAPCs and their endothelial differentiation is due to their pharmacological inefficacy since these two agents have been widely used for a long time as investigational tools and worked well in the range (or less) of concentrations used in this study (Garthwaite et al., 1995; Moellering et al., 1998; Ridnour et al., 2007; Sandirasegarane and Diamond, 1999). These data indicate that the effects of NO on bone marrow stem cell pluripotency and differentiation are independent of sGC-cGMP pathway. Recent studies showed that NO can regulate protein function via the nitrosylation of its cystein residues (Hess et al., 2005). 
Indeed, NO was reported to modulate the function of transcriptional factors such as NF B via nitrosylation (Reynaert et al., 2004). It will be interesting to investigate the role of nitrosylation by NO in MAPC pluripotency and differentiation in future studies.

Taken together, this study demonstrates that NO can modulate both pluripotency and differentiation of bone marrow stem cells. In contrast to its mechanism in inducing vascular relaxation, the effects of NO on stem cell pluripotency and differentiation are independent of sGC-cGMP pathway.

\section{Acknowledgements}

This work was supported by NIH K08 HL075410 (ZL). The authors wish to thank Mr. Dennis E. Mathias for his expert assistance on the preparation of the figures.

\section{References}

Arnhold, S., Klinz, F.J., Bloch, W., Hess, A., Andressen, C., Addicks, K., 1999. Selective expression of the NOS II isoform during mouse vestibulocochlear receptorgenesis. The European Journal of Neuroscience 11, 2187-2193.

Arnhold, S., Fassbender, A., Klinz, F.J., Kruttwig, K., Lohnig, B., Andressen, C., Addicks, K, 2002. NOS-II is involved in early differentiation of murine cortical, retinal and ES cell-derived neurons-an immunocytochemical and functional approach. International Journal Developmental Neuroscience 20, 83-92.

Beckman, J.S., 1999. Parsing the effects of nitric oxide, $S$-nitrosothiols, and peroxynitrite on inducible nitric oxide synthase-dependent cardiac myocyte apoptosis. Circulation Research 85, 870-871.

Ben-Shushan, E., Thompson, J.R., Gudas, L.J., Bergman, Y., 1998. Rex-1, a gene encoding transcription factor expressed in the early embryo, is regulated via Oct-3/4 and Oct6 binding to an octamer site and a novel protein, Rox-1, binding to an adjacent site Molecular and Cellular Biology 18, 1866-1878.

Bloch, W., Fleischmann, B.K., Lorke, D.E., Andressen, C., Hops, B., Hescheler, J., Addicks, K., 1999. Nitric oxide synthase expression and role during cardiomyogenesis. Cardiovascular Research 43, 675-684.

Breyer, A., Estharabadi, N., Oki, M., Ulloa, F., Nelson-Holte, M., Lien, L., Jiang, Y., 2006. Multipotent adult progenitor cell isolation and culture procedures. Experimental Hematology 34, 1596-1601.

Cardounel, A.J., Cui, H., Samouilov, A., Johnson, W., Kearns, P., Tsai, A.L., Berka, V., Zweier, J.L., 2007. Evidence for the pathophysiological role of endogenous methylarginines in regulation of endothelial NO production and vascular function. The Journal of Biological Chemistry 282, 879-887.

Cheng, A., Wang, S., Cai, J., Rao, M.S., Mattson, M.P., 2003. Nitric oxide acts in a positive feedback loop with BDNF to regulate neural progenitor cell proliferation and differentiation in the mammalian brain. Developmental Biology 258, 319-333.

Danalache, B.A., Paquin, J., Donghao, W., Grygorczyk, R., Moore, J.C., Mummery, C.L. Gutkowska, J., Jankowski, M., 2007. Nitric oxide signaling in oxytocin-mediated cardiomyogenesis. Stem cells (Dayton, Ohio) 25, 679-688

Floryszak-Wieczorek, J., Milczarek, G., Arasimowicz, M., Ciszewski, A., 2006. Do nitric oxide donors mimic endogenous NO-related response in plants? Planta 224 (6),1363-1372.

Gallagher, K.A., Liu, Z.J., Xiao, M., Chen, H., Goldstein, L.J., Buerk, D.G., Nedeau, A., Thom, S.R., Velazquez, O.C., 2007. Diabetic impairments in NO-mediated endothelial progenitor cell mobilization and homing are reversed by hyperoxia and SDF-1 alpha. The Journal of Clinical Investigation 117,1249-1259.

Garthwaite, J., Southam, E., Boulton, C.L., Nielsen, E.B., Schmidt, K., Mayer, B., 1995 Potent and selective inhibition of nitric oxide-sensitive guanylyl cyclase by $1 \mathrm{H}-$ [1,2,4] oxadiazolo[4,3-a]quinoxalin-1-one. Molecular Pharmacology 48, 184-188.

Gupta, K., Kshirsagar, S., Li, W., Gui, L., Ramakrishnan, S., Gupta, P., Law, P.Y., Hebbel, R.P., 1999 VEGF prevents apoptosis of human microvascular endothelial cells via opposing effects on MAPK/ERK and SAPK/JNK signaling. Experimental Cell Research 247, 495-504.

Heller, R., Polack, T., Gräbner, R., Till, U., 1999. Nitric oxide inhibits proliferation of human endothelial cells via a mechanism independent of cGMP. Atherosclerosis 144 (1), 49-57.

Hess, D.T., Matsumoto, A., Kim, S.O., Marshall, H.E., Stamler, J.S., 2005. Protein Snitrosylation: purview and parameters. Nature Reviews 6, 150-166.

Jiang, Y., Jahagirdar, B.N., Reinhardt, R.L., Schwartz, R.E., Keene, C.D., Ortiz-Gonzalez, X.R., Reyes, M., Lenvik, T., Lund, T., Blackstad, M., Du, J., Aldrich, S., Lisberg, A., Low, W.C., Largaespada, D.A., Verfaillie, C.M., 2002. Pluripotency of mesenchymal stem cells derived from adult marrow. Nature 418, 41-49.

Kanno, S., Kim, P.K., Sallam, K., Lei, J., Billiar, T.R., Shears 2nd, L.L., 2004. Nitric oxide facilitates cardiomyogenesis in mouse embryonic stem cells. Proceedings of the National Academy of Sciences of the United States of America 101, 12277-12281.

Keefer, L.K., Nims, R.W., Davies, K.M., Wink, D.A., 1996. "NONOates" (1-substituted diazen-1-ium-1,2-diolates) as nitric oxide donors: convenient nitric oxide dosage forms. Methods in Enzymology 268, 281-293.

Krumenacker, J.S., Murad, F., 2006. NO-cGMP signaling in development and stem cells. Molecular Genetics and Metabolism 87, 311-314.

Krumenacker, J.S., Katsuki, S., Kots, A., Murad, F., 2006. Differential expression of genes involved in cGMP-dependent nitric oxide signaling in murine embryonic stem (ES) cells and ES cell-derived cardiomyocytes. Nitric Oxide 14,1-11.

Liu, Z., Jiang, Y., Hao, H., Gupta, K., Xu, J., Chu, L., McFalls, E., Zweier, J., Verfaillie, C., Bache, R.J., 2007. Endothelial nitric oxide synthase is dynamically expressed during bone marrow stem cell differentiation into endothelial cells. American Journal of Physiology. Heart and Circulatory Physiology 293 (3), H1760-1765.

Luttun, A., Schroeder, B.A., Allred, J.A., Adney, J.R., Seaborn, M.S., Nelson-Holte, M.H., Jiang, Y., Verfaillie, C.M., 2005. Expression level of pluripotency marker Oct-4 correlates with in vitro endothelial differentiation potential of multipotent adult progenitor cells. Circulation 112 (Suppl II), II-68.

Maciejewski, J.P., Selleri, C., Sato, T., Cho, H.J., Keefer, L.K., Nathan, C.F., Young, N.S., 1995. Nitric oxide suppression of human hematopoiesis in vitro. Contribution to inhibitory action of interferon-gamma and tumor necrosis factor-alpha. The Journal of Clinical Investigation 96, 1085-1092.

Marks, G.S., McLaughlin, B.E., Jimmo, S.L., Poklewska-Koziell, M., Brien, J.F., Nakatsu, K., 1995. Time-dependent increase in nitric oxide formation concurrent with vasodilation induced by sodium nitroprusside, 3-morpholinosydnonimine, and $S$ nitroso- $N$-acetylpenicillamine but not by glyceryl trinitrate. Drug Metabolism and Disposition 23 (11), 1248-1252.

Moellering, D., McAndrew, J., Patel, R.P., Cornwell, T., Lincoln, T., Cao, X., Messina, J.L., Forman, H.J., Jo, H., Darley-Usmar, V.M., 1998. Nitric oxide-dependent induction of glutathione synthesis through increased expression of gamma-glutamylcysteine synthetase. Archives of Biochemistry and Biophysics 358, 74-82.

Moncada, S., Higgs, A., 1993. The L-arginine-nitric oxide pathway. The New England Journal of Medicine 329, 2002-2012.

Nathan, C., 1992. Nitric oxide as a secretory product of mammalian cells. FASEB Journal 6, 3051-3064.

Niwa, H., Miyazaki, J., Smith, A.G., 2000. Quantitative expression of Oct-3/4 defines differentiation, dedifferentiation or self-renewal of ES cells. Nature Genetics 24, 372-376.

Pan, W., Quarles, L.D., Song, L.H., Yu, Y.H., Jiao, C., Tang, H.B., Jiang, C.H., Deng, H.W., Li, Y.J., Zhou, H.H., Xiao, Z.S., 2005. Genistein stimulates the osteoblastic differentiation via NO/cGMP in bone marrow culture. Journal of Cellular Biochemistry 94, 307-316.

Pesce, M., Scholer, H.R., 2001. Oct-4: gatekeeper in the beginnings of mammalian development. Stem cells (Dayton, Ohio) 19, 271-278.

Peunova, N., Enikolopov, G., 1995. Nitric oxide triggers a switch to growth arrest during differentiation of neuronal cells. Nature 375, 68-73.

Poluha, W., Schonhoff, C.M., Harrington, K.S., Lachyankar, M.B., Crosbie, N.E., Bulseco, D.A., Ross, A.H., 1997. A novel, nerve growth factor-activated pathway involving nitric oxide, p53, and p21WAF1 regulates neuronal differentiation of PC12 cells. The Journal of Biological Chemistry 272, 24002-24007.

Ramakrishna Rao, D.N., Cederbaum, A.I., 1996. Generation of reactive oxygen species by the redox cycling of nitroprusside. Biochimica et Biophysica Acta 1289, 195-202.

Reyes, M., Lund, T., Lenvik, T., Aguiar, D., Koodie, L., Verfaillie, C.M., 2001. Purification and ex vivo expansion of postnatal human marrow mesodermal progenitor cells. Blood 98, 2615-2625.

Reykdal, S., Abboud, C., Liesveld, J., 1999. Effect of nitric oxide production and oxygen tension on progenitor preservation in ex vivo culture. Experimental Hematology 27, 441-450.

Reynaert, N.L., Ckless, K., Korn, S.H., Vos, N., Guala, A.S., Wouters, E.F., van der Vliet, A., Janssen-Heininger, Y.M., 2004. Nitric oxide represses inhibitory kappaB kinase through S-nitrosylation. Proceedings of the National Academy of Sciences of the United States of America 101, 8945-8950.

Ridnour, L.A., Windhausen, A.N., Isenberg, J.S., Yeung, N., Thomas, D.D., Vitek, M.P., Roberts, D.D., Wink, D.A., 2007. Nitric oxide regulates matrix metalloproteinase-9 activity by guanylyl-cyclase-dependent and -independent pathways. Proceedings of the National Academy of Sciences of the United States of America 104 (43), 16898-16903.

Sandirasegarane, L., Diamond, J., 1999. The nitric oxide donors, SNAP and DEA/NO, exert a negative inotropic effect in rat cardiomyocytes which is independent of cyclic GMP elevation. Journal of Molecular and Cellular Cardiology 31, 799-808.

Shami, P.J., Weinberg, J.B., 1996. Differential effects of nitric oxide on erythroid and myeloid colony growth from CD34+ human bone marrow cells. Blood 87, 977-982.

Teixeira, C.C., Ischiropoulos, H., Leboy, P.S., Adams, S.L., Shapiro, I.M., 2005. Nitric oxidenitric oxide synthase regulates key maturational events during chondrocyte terminal differentiation. Bone 37, 37-45.

Ulloa-Montoya, F., Kidder, B.L., Pauwelyn, K.A., Chase, L.G., Luttun, A., Crabbe, A., Geraerts, M., Sharov, A.A., Piao, Y, Ko, M.S., Hu, W.S, Verfaillie, C.M. 2007. Comparative transcriptome analysis of embryonic and adult stem cells with extended and limited differentiation capacity. Genome Biology 8, R163.

Vassilieva, S., Guan, K., Pich, U., Wobus, A.M., 2000. Establishment of SSEA-1- and Oct-4expressing rat embryonic stem-like cell lines and effects of cytokines of the IL-6 family on clonal growth. Experimental Cell Research 258, 361-373.

Villalobo, A., 2006. Nitric oxide and cell proliferation. The FEBS Journal 273, 2329-2344.

Wingrove, J.A., O'Farrell, P.H., 1999. Nitric oxide contributes to behavioral, cellular, and developmental responses to low oxygen in Drosophila. Cell 98, 105-114.

Xia, Y., Cardounel, A.J., Vanin, A.F., Zweier, J.L., 2000. Electron paramagnetic resonance spectroscopy with $\mathrm{N}$-methyl-D-glucamine dithiocarbamate iron complexes distinguishes nitric oxide and nitroxyl anion in a redox-dependent manner: applications in identifying nitrogen monoxide products from nitric oxide synthase. Free Radical Biology \& Medicine 29, 793-797.

Xu, J., Liu, X., Jiang, Y., Chu, L., Hao, H., Liu, Z.H., Verfaillie, C.M., Zweier, J.L., Gupta, K., Liu, Z.G., 2008. MAPK/ERK signaling mediates VEGF-induced bone marrow stem cell differentiation into endothelial cell. Journal of Cellular and Molecular Medicine [Feb 4, Electronic publication ahead of print].

Yan, H., Aziz, E., Shillabeer, G., Wong, A., Shanghavi, D., Kermouni, A., Abdel-Hafez, M., Lau, D.C., 2002. Nitric oxide promotes differentiation of rat white preadipocytes in culture. Journal of Lipid Research 43, 2123-2129.

Yang, D., Zhang, Y., Nguyen, H.G., Koupenova, M., Chauhan, A.K., Makitalo, M., Jones, M.R., St Hilaire, C., Seldin, D.C., Toselli, P., Lamperti, E., Schreiber, B.M., Gavras, H., Wagner, D.D., Ravid, K., 2006. The A2B adenosine receptor protects against inflammation and excessive vascular adhesion. The Journal of Clinical Investigation 116, 1913-1923. 